\title{
The Relationship between Ownership Structure and Firm Performance: An Empirical Analysis over Istanbul Stock Exchange (ISE) Listed Companies
}

\author{
Suleyman Serdar Karaca (Corresponding author) \\ Department of Business Administration, Gaziosmanpasa University \\ E-mail: skaraca01@gop.edu.tr \\ Ibrahim Halil Eksi \\ Department of Business Administration, Kilis 7 Aralik University \\ E-mail: ieksi@kilis.edu.tr
}

Received: May 31, 2011

doi:10.5539/ibr.v5n1p172
Accepted: June 20, 2011

Published: January 1, 2012

URL: http://dx.doi.org/10.5539/ibr.v5n1p172

\begin{abstract}
s
This study investigates the relationship between ownership structure and corporate performance of 50 companies, listed in manufacturing industry on the Istanbul Stock Exchange during the 2005-2008 period. The study uses the share of the largest shareholder as ownership structure variables, tobin's q and profit before tax divided by total asset as performance variables, and leverage and firm size (total asset) as control variables. For variables, first panel unit root and Hausman tests were made and then panel data analysis were applied. Accoarding to the result of analysis, while TLS were observed to have possitive effect on PBT, no effects were observed on TOB.
\end{abstract}

Keywords: Ownership Structure, Firm Performance, ISE, The Share of The Largest Shareholder and Tobin's Q Jel Classification Codes: G30, L25, N20

\section{Introduction}

The relationship between ownership structure and corporation performance is one that has received considerable attention in finance literature (Jiang 2004).

For a few decades, ownership structure has been an appealing subject for scholars and analysts. The first study within the theory of the firm on the modern corporation was done by Berle and Means in 1932. They debated over conflicts of interest between controllers and managers. They asserted that with growing diffusion of ownership, the power of shareholders to control management is reduced. As a result, they suggested that a negative correlation exist between ownership concentration and a firm's performance (Bargezar and Babu 2008).

Demsetz (1983) put a counter argument by observing that it is unreasonable to suppose that the diffused ownership structure dilutes profit maximization objective as a guide for resource allocation and utilization. He argued that the ownership structure is an 'endogenous' element for maximizing the profit and value of a corporate entity. When the requirement of capital is large for achieving scale rapidly, there is a need to meet the requirement (of capital) by making offer to the public at large to contribute to the equity share capital of a firm. Subscription by the members of public to the equity share capital of a firm leads to diffusion of ownership structure. Thus, the value enhancement of a corporate entity by achieving scale requires a diffused ownership structure, as single ownership is not enough to maximize the value of a firm (Ganguli and Agrawal 2009).

In general, a positive relation between ownership concentration and firm efficiency is predicted and many studies have confirmed it. Further, Stulz (1988) formalised a concave relationship between managerial ownership and firm valuation: an increase in managerial ownership and control will first increase firm value; but at a higher level of managerial ownership, firm value will decrease because of entrenchment effects (Driffield at al. 2006).

Early studies such as Vernon (1966) and Caves (1974) suggested that multinational firms are more productive than their domestic counterparts and that the presence of multinational firms has a positive impact on domestic firms' performance. Foreign direct investment (FDI) by multinational firms has since been advocated as a primary source 
of technology diffusion and economic growth for developing countries. In addition to having positive impacts on trade, employment and capital, FDI has also been viewed as a key channel for transferring knowledge, skills, and technology, especially from industrialized to developing countries (Yasar and Poul 2007).

Ownership structure has two implications; i.e. structure of ownership (share percents of state, legal or institution, domestic individual holders) and ownership concentration (share percents of top five or 10 holders). The typical achievement among ownership structure and firm performance researches are the results of Jensen and Meckling. They divided shareholders into internal (investors with management right) and external shareholders (investors without ballot right). The conclusion of their research was that value of a firm depends on the internal shareholder's share, which is called ownership structure. Theoretically, the more the internal shareholder's share the higher the firm value. The researchers also defined firm value as a function of ownership structure. Because ownership structure has links with corporate governance, it can have both positive and negative effects on corporation governance (Jiang 2004).

Some shareholders may be entirely passive investors, whereas others are more active and do perform an important monitoring service. Various motivations and abilities of different types of shareholders may result in their distinctive effectiveness to influence major corporate decisions and value. Managerial ownership (insider ownership) is the most popular topic that has been extensively studied (Hu 2008)

The main objective of this study was to investigate the relationship between ownership structure and corporate performance. The study focuses on the relationship between ownership structure and corporate performance. For this purpose, the study investigated Turkish companies.

\section{Literature Review}

A number of studies have dealed with and discussed the relationship between concentrated ownership and firm performance, the impact of ownership structure on the performance and the relationship between stockholders and managers.

\subsection{Literature in The World}

Leech and Leahy (1991) argue that ownership concentration fundamentally constrains managerial diversion from shareholder interests by determining the distribution of voting power and the control among shareholders. Thomsen and Pedersen (2000) also write that ownership concentration measures the power of shareholders to influence managers. These indicate that it has positive relationship with firm value. Moreover, Denis and McConnell (2003) write that concentrated ownership has a positive relationship with firm value most often. The contrasting view is that the increase in ownership concentration has the danger of entrenched block shareholders that may lead to decrease in firm value. However, there are arguments stating that the relationship is not uniform and systematic. On UK firms, Cubin and Leech (1983) find positive relationship between ownership concentration and accounting profitability measures. Moreover, Lloyd et al. (1987) find greater market-to-sales ratio for owner-controlled companies with ownership concentration.

However, Thomsen and Pedersen (2000) find a non-linear relationship between ownership concentration and firm performance for a sample of largest European firms, ownership concentration shows positive relation up to a certain level, beyond which it shows a negative effect. Leech and Leahy (1991) provide evidence that ownership concentration has a negative impact on valuation ratio, trading profit margin and growth in net assets on UK firms. They find that the greater dispersion of ownership the higher is valuation ratio, profit margin, and growth rate of net assets, depending upon control type. Slovin and Sushka (1993) also find significant excess return following the death of inside blockholders, which they find reducing ownership concentration, thus, indicating negative relation between ownership concentration and firm value. Additionally, adjusting for firm characteristics and fixed effects, Cronqvist and Nilsson (2003) find a significant negative effect of vote ownership of controlling minority shareholders and firm value measured in Tobin's Q, and that ROA is lower for firms with concentrated vote control for Swedish firms.

Lemmon and Lins (2003) studied the effect of ownership structure on changes in shareholder value during the East Asian Financial crisis that began in July 1997. They use the data from 800 firms in eight Asian countries, they found evidence consistent with this view. Cumulative stock returns of firms in which managers and their families separate their control and cash flow rights through pyramid ownership structures are lower by 12 percentage during the crisis period compared to those of other firms. Further, they find that the stock return underperformance associated with pyramid ownership structures was present only in firms where the management group also had a high level of control. The under- performance increases to about 20 percentage for these firms. Finally, during the precrisis period, 
we find no evidence that firms with a separation between managerial cash flow rights and control rights exhibit changes in performance different from firms with no such separation.

Miguel, Pindado and Torre (2004) rely on theoretical arguments pointing to the non-linearity of the relationship, two empirical models are specified that allow them to derive the optimal break points in both the relationship between value and ownership concentration, and the relationship between value and insider ownership. Their results showed a quadratic relationship between value and ownership concentration, which confirms not only the monitoring, but also the expropriation effect for the very highest concentration values in Span ish firms, in contrast to the previous findings for U.S., U.K., German, and Japanese firms. Concerning insider ownership, their evidence supports both the convergence-of-interest and the entrenchment effects, and suggests that Spanish insiders get entrenched at higher ownership level than their U.S and U.K. counterparts. In model 1, they suggested that the value of Spanish firms rises as ownership concentration increases from 0 percent to 87 percent as a clear consequence of the more efficient monitoring provided by concentrated share holding and that beyond this breakpoint firm value is negatively affected by ownership concentration since an ownership structure that is so concentrated allows the expropriation of minority shareholders. In model 2, they suggest that for insider ownership values between 0 percent and 35 percent any increment in this variable will be translated into increments in value, as a consequence of the greater incentives for insiders to maximize value as their stakes rise. When ownership ranges from 35 percent to 70 percent, value decreases as insider ownership rises; this result suggests that increases in ownership between 35 percent and 70 percent cause insiders to be less interested in the welfare of the rest of the shareholders, and that their higher stakes are likely to entrench them. Finally, for the very highest ownership levels above 70 per cent the convergence-of-interest seems to dominate the relation again.

The most recent study conducted by Barbosa and Louri (2005) investigated if MNEs operating in Porugal and Greece perform differently than their domestic counterparts. The final simple is considered of 523 manufacturing firms' data produced by Portuguese Ministry of Labour in 1992 and based on Standard survey that must be answered by firms with wage earners every year. In the Greek situation, 2,651 firms are used and data has been obtained from ICAP directory in 1997. After using the robust method of quintile regression, the results suggest that ownership ties do not make a significant difference with corresponding to the firm performance in Portugal and Greece.

Alan and Steve (2005) looked at the short and long term performance of UK corporations acquired by foreigners. The findings on 333 overseas acquisitions by UK limited companies fort he period 1984-1995 reveal significant positive returns on the firm performance.

Chen at al.(2005) analyzed a sample of 412 publicly listed Hong Kong firms during 1995-1998 in order to answer three questions. Does concentrated family ownership affect firm operating performance and value? Does it affect dividend policy? What is the impact of corporate governance on performance, value, and dividend payouts? Their results do not show a positive relationship between family ownership and return on assets, return on equity or the market-to-book ratio. In addition, they find a negative relationship between CEO duality and performance (where CEO duality is much more likely in family-controlled firms).

Bhabra (2007) conducted a study over the New Zeland firms during 1994-1998. He used Tobin's q as dependent variable and block shareholders, firm scale (in terms of total sales), development opportunities and leverage as control variables. In his study, he observed a non-linear relationship between internal ownership and firm value.

$\mathrm{Li}$ at al.(2007) examined the relationship between managerial ownership and firm performance for a sample of Chinese State-owned enterprises (SOEs) privatized over the period 1992-2000. The results indicated that managerial ownership has a positive effect on firm performance. Although return on assets (ROA) and return on sales (ROS) decline post-privatization, firms with high managerial ownership and, specially, high CEO ownership, exhibit a smaller performance decline. The difference is highly significant, with or without controlling for residual state ownership and changes in the firm's operating environment. They also find that the influence on firm performance becomes less significant at higher levels of CEO ownership. In contrast, performance continues to increase with managerial ownership. This finding suggests that, beyond a certain point, the distribution of shares would be more effective if extended to the whole management team instead of being limited to the chief executive.

Bargezar and Babu (2008) investigated the relationship between ownership structure and corporate performance of top 50 companies listed on the Tehran Stock Exchange during the period 2001-03. In the study, the ownership structure is considered in terms of institutional and non-institutional ownership. The study uses Returns on Asset (ROA), Return on Equity (ROE), and Tobin's Q ratios as measures of firm performance. The results indicate that there is a positive relationship between institutional ownership and firm performance in the case of Iran. In addition, it is found that ownership structure is highly concentrated and firms with diffused ownership have performed better 
than those with concentrated ownership. In addition, there is a significant negative relationship between performance and company size, and finally the relationship between debt-to-asset ratio and performance is significant.

\subsection{Liretature in Turkey}

Gunduz and Tatoglu (2003) studied about foreign owned firms' performance in Turkey. They employed the one-way analysis of variance (ANOVA) to investigate the effect of foreign ownership on performance of 202 non-financial firms listed on ISE in 1999. The findings revealed that foreign owned firms have significantly beter performance than domestic firms regarding with ROA, but no in other financial performance ratios.

Yildirim and Demireli (2009) conducted a study on the manufacturing firms during 2002-2006. On their study, they used assets, sales, return on equity and tobin's q rates as dependent variables and the share of the largest shareholder, dominance of the general assembly as independent variables and sales figures, leverage as control variables and sub-sectors as sector variables. As a result of their studies, they observed that the profitability of assets, the profitability of sales and return on equity decreased but tobin's q rates increased with increasing power and control over the ownership of the company's largest shareholder.

Mandaci and Gumus (2010) found that the empirical results on the effects of managerial ownership and ownership concentration on firm performance are conflicting. Previous studies focused mostly on large industrialized countries, which completed their institutionalization process and therefore, their outcomes might not be relevant for developing countries. In their study, they try to fill this gap by examining the effects of ownership concentration and managerial and industry dummies, which are assumed to have an effect on firm performance. In addition, they analyzed the ownership structure of the sample firms and found that the highest average percentage of shares was held by the unlisted holding companies, unlisted non-financial firms and individuals and families, respectively, which confirms the widespread belief that in Turkey individuals or families set up their unlisted firms in order to control their listed companies.

Samiloglu and Unlu (2010) investigated the relationship between ownership concentration and the firm performance for Turkish listed companies. (ISE 100). This study covers 70 firms which traded in ISE 100 index, having appropriate data structure. The sample period of the study has also been determined as 2002-2007. As a result, in this study a significant relationship couldn't be found statistically between ownership structure and both market and accounting based performance metrics.

Tanrioven and Aksoy (2010) examined The Partnership Concentration on the Companies Operating in Istanbul Stock Exchange and the Effects on the Firms Performance. The ownership structures are expected to have impact on company performance. In order to examine the impacts of different ownership structure on company performance, regression analysis has been used with 113 companies' data operating in the period 1996-2009 in Istanbul Stock Exchange. In the analysis ROA (Return on Asset), ROE (Return on Equity) and Net Profit Margin have been used as performance variables; concentration, board of directors' size and the proportion of three major partner's share have been used as concentration variables. Those have been determined in the analysis results that generally sales size and profit growth have affected all dependent variables positively; leverage, short-term debt ratio, operating risk and sales structure negatively. Moreover, those have been determined that concentration has affected ROA and TobQ; board of directors' size has affected ROA and TobQ and the three major partner's share has affected TobQ positively.

Bayrakdaroglu (2010) aimed to examine relationship between dependent (such as Tobin's q, ROE and ROA) and independent (ownership concentration, free float rate, foreign ownership and managerial ownership) variables with the help of the panel regressions. Thus, the relationship between ownership structure and financial performance were tested. According to the results obtained from the study, in the context of different models of ownership structure variables have an effect on the financial performance of companies that may be expressed. In general, while ownership concentration and free float rate variables have an effect on financial performance, foreign ownership and managerial ownership variables which measures ownership structure are not found to be statistically significant affect on financial performance

\section{Methodology}

In the application part of the study, it was tested whether there was emprically relationship between firm performance values and ownership structure. The presence of this relationship was analyzed using panel data econometrics for the 2005-2008 period. In this part of the study used panel unit root tests, panel regression analysis and Hausman tests were briefly described in terms of the theoretical aspects. 


\subsection{Panel Unit Root}

As in all time series analysis there be forged relationship in panel data analysis containing a combination of both time and horizontal cross- sectional analysis. To eliminate this situation, variables must be stationary.

Testing for unit root in time series studies is now a standard practice among researchers. However, testing for unit roots in panels is relatively recent. The development of panel data technique has challenged the traditional pure time series methods, principally because it requires fewer time series observation. This in our view is important as we may have to focus on short time spans such as the post crisis period (Baharumshah at al., 2007).

Unit root tests used in the panel data study could be examined in two parts. The tests in the first group (like Im, Pesaran, Shin) and Fihser- oriented tests (like ADF and PP Tests) are called individual unit root tests. Levin, Lin, Chu (2002); Breitung (2000) and Hadri (2000) unit root tests are referred to as the common unit root test (Cetin and Ecevit, 2010). In this study, PP-Fisher and Hadri-Z unit root tests were used. PP-Fisher and Hadri-Z tests were used to test the different hypotheses. While in Hadri-Z unit root test, Zero Hypothesis is established as there is no unit root, in the PP-Fihser unit root test, Zero Hypothesis is to test as there is unit root.

\subsection{Panel Data}

In economic researches different data types can be used such as time series, cross section data and time series-cross section data. Panel data is a method used to estimate the economic relationship with cross section series which has time dimension.

Panel data is a data set where there are time series which belong to multiple sections. When every section has equal length, time series are called balanced panel data and when time series length differs among sections are called unbalanced panel data (Atalay, 2007)

Simple function of Panel data is;

$$
\text { Yit }=\alpha+\beta i t * X i t+\ldots . .+\beta \text { kit*Xkit+eit }
$$

$\mathrm{i}=1,2,3, \ldots . ., \mathrm{Nt}=1,2, \ldots . ., \mathrm{T}$

In equation $1, \mathrm{i}$ stands for section whereas $\mathrm{t}$ for time. In this equation, there is an individual effect which includes properties that belong to sections but doesn't change with time, can't be observed with independent variables and there is an error term including different properties belong to different units. This kind of models are known as one-sided error component regression models (Baltagi, 2005) .

Error term in most of the studies is shown as;

$$
\text { eit }=\mu \mathrm{i}+v \text { it }
$$

In equation $2, \mu \mathrm{i}$ is called individual effect and changes from section to section without depending on time. vit can change with both time and section. So $\mu$ i shows un-observable section effect, vit shows stochastic error term. One-sided error component models consist of only section effect and stochastic error terms. Models which include unobservable time effects are called two-sided error component regression models. Two-sided error component regression models can be shown as this;

$$
\text { eit }=\mu \mathrm{i}+\lambda \mathrm{t}+\mathrm{vit}
$$

In equation (3), $\lambda \mathrm{t}$ is a variable that affects whole sections and belongs to only one time zone and cannot be expressed by other variables. With these assumptions vit stands for unobservable time effect (Ozer and Ciftci,2009).

One and two sided error component models are divided into two groups depending on assumptions individual and time effects on the error term. Model named fixed effect models when one sided error term predicted the individual effect and when two sided error term both individual predicted and term effects, assumed as the fixed effects that has to be predicted. Another model is random effect model (Atalay, 2007).

In fixed effect models it is assumed that $\mu \mathrm{i}$ is fixed which stands for unobservable horizontal section effects, vit has zero mean and has normal distribution with fixed variance. In this model, we have $\mathrm{N}$ equation with some slope but different intersection point. As a result fixed effect method allows a flexible expression of the heterogeneity between sections (Simsek, 2008).

In the random effect models, differences on units or units and time, is including in the model as a component of error term. This is to prevent the loss of degree of freedom. In the random effect model it is important to find special error components that belong to unit or unit and time rather than finding special parameters that belong to unit or unit and time. Moreover in the random effect model, it is taking into account the effects that come from outside of sample as well the effects of observable sample section, units and time (Pazarlioglu and Gurler, 2007). 


\subsection{Hausman Test}

Hausman test was used to determine whether to use fixed effect (predicting different coefficient for each country on data set) or random effect (predicting different coefficient for each country in dataset in a randomly manner) for datasets which includes short time section or has similar properties. Hausman test is to test hypoteses as follows;

Ho:fixed effect estimates and random effect estimates are equal (random effect)

H1: fixed effect estimates and random effect estimates are different from each other (no random effects)

\subsection{Model and Data}

In the study, firms quoted during the 2005-2008 period and operated in the manufacturing industry on Istanbul Stock Exchange were examined. Finance companies and holding companies were excluded from the study. In addition, firms excluded from ISE quotation because of bankruptcy, merger or any causes were not included in the study because these firms don't provide continuity constraint. In the analysis, 50 firms operated in the manufacturing industry were examined in 4 years period. The reason for keeping the small number of firms is the request balanced of serial. In the study, data of the firms were ensured from company financial statements and yearbooks from Official Website of the Istanbul Stock Exchange. Statistical analysis was carried out using EViews 7.0 package programme.

Variables used in the study were collected in three groups as dependent, independent and control variables.

Insert Table 1 Here

The purpose of our study was to examine effects on profit before tax and tobin's q variables of the firm ownership structure. At this point, hypotheses we tested is effective on tobin's q variable and profit before tax variable of ownership structure.

In the study, two regression models between variables are as follow;

$$
\begin{aligned}
& \text { TOBit }=\alpha+\beta \text { itLEV it }+\beta \text { iSIZ it }+\beta \text { iTLS it }+ \text { eit } \\
& \text { PBTit }=\alpha+\beta \text { itLEV it }+\beta \text { iSIZ it }+\beta \text { iTLS it }+ \text { eit }
\end{aligned}
$$

In equations $i$ and $t$ stands for firms and years respectively. $e_{i t}$ is error term.

\section{Research Findings}

Emprical findings of the study are examined in four section as general statistics for the variables, the results of unit root and Hausman test and panel regression analysis.

\subsection{Descriptive Statistics and Correlations}

\section{Insert Table 2 Here}

In the statictics in the table 2 were observed that the average TOB values are 0,866 , PBT values are 0,021 , LEV values are 0,47 , SIZ values are $267.346 .602 \mathrm{TL}$ and TLS values are $49.87 \%$. In the table 2 , it draws attention in excess of standart deviation of the total assets as indicator of the scale of the firm.

Insert Table 3 Here

In correlation table draws attention to a positive correlation between TOB, PBT and TLS.

\subsection{The results of Unit Root}

In our study before unit root tests, unit root test done which is to be applied in the form (including intercept, including intercept and trend and none) is determined by Panel Least Squares Method. Detection of this effect by applying, while variables with unit root are purified the unit root, are provided to prevent data loss.

In the other words, instead of immobilization by taking the difference of variables with unit root, purifying of the resulting effect, by revealing a series of new, unit root test are made with a series of new.

Insert Table 4 Here

According to the result of analysis of panel unit root tests, tests are shown that it is not unit root of series. As shown in table 1 , for $p$-values calculated are much smaller than the critical value of 0,05 are refused hypoteses that denoting the series contains unit root.

As can be seen these results, it can be said it is not a common unit root process in series and unit root process for each unit. 


\subsection{Hausman Test and Panel Regression Statistical Results}

In Hausman Test performed for the first model, tobin's q is the dependent variable, were determined that random effect should be used both cross section and the size of period. In Hausman Test performed for the second model, PBT value is the dependent variable were determined that should be used fix for cross section and random effect for period.

Insert Table 5 Here

In the model observed that leverave valiable has only a significant effect on tobin's q that refers to firm performance. It wasn't observed that other valiables as the share of the largest shareholder and asset size has contribution on the model. Model was determined as follow;

$$
\mathrm{TOB}=0.842-1.584165 \mathrm{LEV}
$$

Insert Table 6 Here

In the model, the share of the largest shareholder and leverage valiables appear to be the factors affecting the firm performance. Asset size has no significant effect on the firm performance. The model created in the following way;

$$
\text { PBT }=0.162+0.001 \mathrm{TLS}-0.323 \mathrm{LEV}
$$

\section{Conclusion}

The main objective of this study is to investigate the relationship between ownership structure and corporate performance. The study focuses on the relationship between ownership structure and corporate performance. For this purpose, the study investigates Turkish companies. Ownership structure has two implications structure of ownership (share percents of state, legal or institution, domestic individual holders) and ownership concentration (share percents of top five or 10 holders).

In our study we analyzed the relationship between ownership concentration and firm performance, the share of the largest shareholder valuable was used to represent the degree of ownership concentrated. The share of the largest shareholder is observed to be effective on PBT with a significant and positive coefficient as statistical in the panel data. Whereas it has no positive effect on TOB. In the literature was observed studies that as it was meaningless relationship between ownership structure and firm performance as Samiloglu and Unlu's study. According to the result of their study a significant relationship couldn't be found statistically between ownership structure and both market and accounting based performance metrics. They found a weak relationship between dependent and independent variables. Their conclusions are consistent with the results of the other studies that unable to detect a strong relationship in the literature and was observed tha it was meaning relationship between ownership structure and firm performance in studies.

In our study, PP-Fisher and Hadri-Z unit root tests were used. The results of unit root tests indicate that series has no unit root. In the first model, The share of the largest shareholder ratio as the independent variable did not have statistically a significant effect on Tobin q ratio as the dependent variable. In the second model, The share of the largest shareholder ratio as the independent variable have statistically a significant and positive effect on PBT ratio as the dependent variable.

\section{References}

Alan Gregory, \& Steve McCorriston. (2005). Foreign acquisitions by UK limited companies: short- and long-run performance. Journal of Empirical Finance, 12, 99- 125. http://dx.doi.org/10.1016/j.jempfin.2003.10.003.

Alberto De Miguel, Julio Pindado, \& Chabela De La Torre. (2004). Ownership Structure and Firm Value: New Evidence from Spain. Strategic Management Journal, 25(12), 1199-1207. http://dx.doi.org/10.1002/smj.430.

Atalay,S. Serpil. (2007). Yeni Avrupa Birliği Ülkelerinde Ve Türkiye'de Reel Yakınsama. Türkiye Cumhuriyet Merkez Bankası Uzmanlık Yeterlilik Tezi.

Bahram Barzegar, \& K Nagendra Babu. (2008). The Effects of Ownership Structure on Firm Performance: Evidence from Iran. The Icfai Journal of Applied Finance, 14(3), 43-55.

Baharumshah Ahmad Zubaidı Raj Aggarwal, \& Chan Tze Haw. (2007). East Asian Real Exchange Rates and PPP:New Evidence from Panel-data Tests. Global Economic Review, 36(2), 103-119. http://dx.doi.org/10.1080/12265080701374024.

Bhabra Gurmeet Singh. (2007). Insider ownership and firm value in New Zealand. Journal of Multinational Financial Management, 17, 142-154. http://dx.doi.org/10.1016/j.mulfin.2006.08.001.

BALTAGI, Badi. (2005). Econometric Analysis Of Panel Data.(3rd ed. ). John Wiley And Sons Ltd. 
Bayrakdaroglu, Ali. (2010). Ownership Structure and Financial Performance; An ISE Case. Ekonomi Bilimleri Dergisi, 2(2), 11-20.

Cubbin, J. \& Leech, D. (1993). The Effect of Shareholding Dispersion on the Degree of Control in British Companies: Theory and Measurement. The Economic Journal, 93(June), 351-369.

Cronqvist, H., \& Nilsoson, M. (2003). Agency Costs of Controlling Minority Shareholders. Journal of Financial and Quantitative Analysis, 38(4), 695-714. http://dx.doi.org/10.2307/4126740.

Donghui Li, Fariborz Moshirian, Pascal Nguyen, \& Li-Wen Tan. (2007). Managerial ownership and firm performance: Evidence from China's privatizations. Research in International Business and Finance, 21, 396-413. http://dx.doi.org/10.1016/j.ribaf.2007.02.001.

Denis, D. K., \& McConnell, J. J. (2003). International Corporate Governance. Journal of Financial and Quantitative Analysis, 38(1), 1-36. http://dx.doi.org/10.2307/4126762.

Demsetz,H., \& Villalonga, B. (2001). Ownership Structure and Corporate Performance. Journal of Corporate Finance, 7, 209-233. http://dx.doi.org/10.1016/S0929-1199(01)00020-7.

Driffield, Nigel Vidya Mahambare, \& Sarmistha Pal. (2006). How Does Ownership Structure Affect Capital Structure and Firm Performance? Recent Evidence from East Asia.

Hu, Yabei. (2008). The Relationship Between Ownership and Performance: A Review of Theory and Evidence. International Business Research, 1(4), 72-81.

Jiang, Ping. (2004). The Relationship Between Ownership Structure and Firm Performance: an Empirical Analysis over Heilongjiang Listed Companies. Nature and Secience, 2 (4), 87-90.

Lokman Gunduz, \& Ekrem Tatoglu. (2003). A Comparison Of The Financial Characteristics Of Group Affiliated And İndependent Firms İn Turkey. European Business Review, 15(1), 48-54. http://dx.doi.org/10.1108/09555340310455191.

Leech, D., \& Leahy, J. (1991). Ownership Structure, Control Type Classifications and the Performance of Large British Companies. Economic Journal, 101, 1418-1437. http://dx.doi.org/10.2307/2234893.

Lloyd, W. P., Modani, N. K., \& Hand, J. H. (1987). The Effect of the Degree of Ownership Control on Firm Diversification, Market Value, and Merger Activity. Journal of Business Research, 15(4), 303-312. http://dx.doi.org/10.1016/0148-2963(87)90002-6.

Mandacı, Pınar Evrim, \& Guluzar Kurt Gumus. (2010). Ownership Concentration, Managerial Ownership and Firm Performance: Evidence from Turkey. SEE Journal, 57-66.

Michael L. Lemmon, \& Karl V. Lins. (2003). Ownership Structure, Corporate Governance, and Firm Value: Evidence from the East Asian Financial Crisis. The Journal of Finance, 58(4), 1445-1468. http://dx.doi.org/10.1111/1540-6261.00573.

Murat ÇETIN, \& Eyyup ECEVITT. (2010). Sağlık Harcamalarının Ekonomik Büyüme Üzerindeki Etkisi: Oecd Ülkeleri Üzerine Bir Panel Regresyon Analizi. Doğuş Üniversitesi Dergisi, 11(2), 166-182.

Mustafa ÖZER, \& Necati Çiftçi. (2009). Ar-Ge Harcamaları Ve Đhracat Đliskisi: OECD Ülkeleri Panel Veri Analizi. Dumlupinar Üniversitesi Sosyal Bilimler Dergisi, S. 23, Nisan 2009.

Natallıa Barbosa, \& Helen Lourı. (2005). Corporate Performance: Does Ownership Matter? A Comparison of Foreign- andDomestic-Owned Firms in Greece and Portugal. Review of Industrial Organization, 27, 73-102. http://dx.doi.org/10.1007/s11151-005-4920-y.

Pazarlığlu, Vedat, M., \& Özlem Kiren Gürler. (2007). Telekomünikasyon Yatırımları Ve Ekonomik Büyüme: Panel Veri Yaklaşımı. Finans Politik\& Ekonomik Yorumlar, 44, 508.

Samiloglu, Famil, \& Ulas Unlu. (2010). The Relationship Between Ownership Structure and Firm Performance. The Journal of Accounting and Finance, 46, 66-73.

Santanu K Ganguli, \& Shail Agrawal. (2009). Ownership Structure and Firm Performance: An Empirical Study on Listed Mid-Cap Indian Companies. The IUP Journal of Applied Finance, 15(12), 37-52.

Slovin, M. B., \& Sushka, M. E. (1993). Ownership Concentration, Corporate Control Activity, and Firm Value: Evidence from the Death of Insider Blockholders. The Journal of Finance, 4, 1293-1321. http://dx.doi.org/10.2307/2329039.

Şimşek, Nevzat. (2008). Türkiye'nin Endüstri-İçi Dış Ticaretinin Analizi, Beta Yayınevi, İstanbul, 1. Basım 
Tanrioven, Cihan, \& Emine Ebru Aksoy. (2010).The Partnership Concentration on the Companies Operating in Istanbul Stock Exchange and the Effects on the Firms Performance. 46, 216-231.

Thomsen, S., \& Pedersen, T. (2000). Ownership Structure and Economic Performance in the Largest European $\begin{array}{lllll}\text { Companies. } & \text { Strategic } & \text { Management } & \text { Journal, } & \text { 21(6), }\end{array}$ http://dx.doi.org/10.1002/(SICI)1097-0266(200006)21:6<689::AID-SMJ115>3.0.CO;2-Y.

Yasar Mahmut, \& Catherine J. Morrison Poul. (2007). Firm Performance and Foreign Direct Investment: Evidence from Transition Economies. Economics Bulletin, 15(21), 1-11.

Zhilan Chen, Yan-Leung CheungT, Aris Stouraitis, \& Anita W.S. Wong. (2005). Ownership concentration, firm performance, and dividend policy in Hong Kong. Pacific-Basin Finance Journal, 13, 431- 449. http://dx.doi.org/10.1016/j.pacfin.2004.12.001.

Table 1. Variables, Formula and Symbol

\begin{tabular}{|l|l|l|l|}
\hline Variables & & Formula & Symbol \\
\hline Dependent Variables & $\begin{array}{l}\text { Tobin's q } \\
\text { Profit before Tax }\end{array}$ & $\begin{array}{l}\text { Market Value / Total Asset } \\
\text { Profit before tax / Total Asset }\end{array}$ & $\begin{array}{l}\text { TOB } \\
\text { PBT }\end{array}$ \\
\hline Control Variables & $\begin{array}{l}\text { Leverage } \\
\text { Size of Assets }\end{array}$ & $\begin{array}{l}\text { Total Dept / Total Assets } \\
\text { Total Asset }\end{array}$ & $\begin{array}{l}\text { LEV } \\
\text { SIZ }\end{array}$ \\
\hline Independent Variables & The Share of The Largest Shareholder & The Share of The Largest Shareholder / Total Equity & TLS \\
\hline
\end{tabular}

Table 2. Descriptive Statistics

\begin{tabular}{|l|l|l|l|}
\hline Variables & Mean & Median & S.D. \\
\hline TOB & 0,866 & 0,618 & 0,913 \\
\hline PBT & 0,021 & 0,02 & 0,161 \\
\hline LEV & 0,47 & 0,44 & 0,234 \\
\hline SIZ & $2,67 \mathrm{E}+08$ & $1,14 \mathrm{E}+08$ & $4,84 \mathrm{E}+08$ \\
\hline TLS & 49,87 & 49,5 & 21,544 \\
\hline
\end{tabular}

Table 3. Correlastions

\begin{tabular}{|l|l|l|l|l|l|}
\hline & TOB & TLS & LEV & PBT & SIZ \\
\hline TOB & 1,000 & 0,316 & $-0,269$ & 0,232 & 0,007 \\
\hline TLS & 0,317 & 1,000 & $-0,179$ & 0,252 & 0,118 \\
\hline LEV & $-0,269$ & $-0,179$ & 1,000 & $-0,510$ & $-0,153$ \\
\hline PBT & 0,232 & 0,252 & $-0,510$ & 1,000 & 0,205 \\
\hline SIZ & 0,007 & 0,118 & $-0,153$ & 0,205 & 1,000 \\
\hline
\end{tabular}

Table 4. Panel Unit Root Result

\begin{tabular}{|l|l|l|l|l|l|}
\hline Variables & Model & P Value & Statistic & Result & Method \\
\hline TOB & Intercept and trend & $0.0000^{*}$ & 297.6 & $\mathrm{I}(0)$ & Hadri z \\
\hline PBT & Intercept & $0.0002^{*}$ & 158.518 & $\mathrm{I}(0)$ & PP-Fisher \\
\hline LEV & Intercept & $0,0000^{*}$ & 179.557 & $\mathrm{I}(0)$ & PP-Fisher \\
\hline SIZ & Intercept & $0,0000^{*}$ & 164.925 & $\mathrm{I}(0)$ & PP-Fisher \\
\hline TLS & Intercept & $0,0097^{*}$ & 135.975 & $\mathrm{I}(0)$ & PP-Fisher \\
\hline
\end{tabular}

*significance levels at $\% 1$

Table 5. The Panel Data Results Of Model 1

\begin{tabular}{|l|l|l|l|l|}
\hline Variable & Coefficient & Std. Error & t-Statistic & Prob. \\
\hline LEV & -1.584165 & 0.415497 & -3.812695 & $0.0002 *$ \\
\hline TLS & 0.002931 & 0.006301 & 0.465108 & 0.6425 \\
\hline SIZ & $-3.67 \mathrm{E}-10$ & $4.62 \mathrm{E}-10$ & -0.793583 & 0.4287 \\
\hline C & 0.842761 & 0.211807 & 3.978907 & 0.0001 \\
\hline
\end{tabular}

*significance levels at $\% 1$ 
Table 6. The Panel Data Result Of Model 2

\begin{tabular}{|l|l|l|l|l|}
\hline Variable & Coefficient & Std. Error & t-Statistic & Prob. \\
\hline TLS & 0.001192 & 0.000569 & 2.096708 & $0.0373^{* *}$ \\
\hline LEV & -0.323157 & 0.050867 & -6.35292 & $0.0000^{*}$ \\
\hline SIZ & $3.71 \mathrm{E}-11$ & $2.59 \mathrm{E}-11$ & 1.431461 & 0.1539 \\
\hline C & 0.162965 & 0.028521 & 5.713928 & 0.0000 \\
\hline
\end{tabular}

*significance levels at $\% 1-* *$ significance levels at $\% 5$ 